\title{
Capital Budgeting Practices in Financial Institutions (FIs): An Empirical Study in the Case of Ethiopia
}

\section{Dakito Alemu Kesto ${ }^{1^{*}}$, Jaladi Ravi}

${ }^{1}$ Research Scholar, Department of Commerce and Management Studies, Andhra University, Visakhapatnam, Andhra Pradesh, 530003, INDIA

${ }^{2}$ Professor, Department of Commerce and Management Studies, Andhra University, Visakhapatnam, Andhra Pradesh, 530003, INDIA

*Corresponding Contact:

Email: dalemu22@gmail.com

\begin{abstract}
Capital budgeting is the process that requires planning for setting up budgets on projects expected to have long-term implications, which is used as a standard for decision making for any organization. This study attempts to explore the capital budgeting practices in FIs and to ascertain if they had guidelines for capital budgeting techniques. The finding shows that, even if the firms in the sector have made significant investment on long-term assets only $42.9 \%$ of the firms were properly practiced the modern approaches of investment evaluation methods. Moreover, the most commonly used long-term investment evaluation techniques were PBP, NPV and IRR respectively. On the other hand, except one firm, which conducts partial analysis about the feasibility, almost all other firms in the sector did not make detail evaluation about the feasibility of investment while opening new branches which similar to study conducted by Eyob Dagne (2010). Similarly, the study also found negligence on the application of cost of capital as most firms were found using the cost of debt while discounting their cash flows despite the fact that most firms were found financing their projects using both debt and equity. In a similar vein, less than $30 \%$ of firms in the sector, of those apply capital budgeting techniques while evaluating long-term assets, used risk evaluation approaches. On top of this, inflation is also an area where firms have not paid much attention in their capital budgeting decision making. The study concluded by opening area for further research on how capital budgeting could be used for efficient resource allocation in the process of budgeting in developing countries.
\end{abstract}

Key Words: Cost of capital, capital budgeting technique, PBP, net present value, IRR

\section{INTRODUCTION}

One of the areas that is likely to determine the success or failure of a firm is its investment decision on long lived assets, in this regard Dayananda, Irons, Harrison, Herbohn and Rowland (2002) noted that Sizable, long-term investments in tangible or intangible assets have long-term consequences. An investment today will determine the firm's strategic position many years 
hence. These investments also have a considerable impact on the organization's future cash flows and the risk associated with those cash flows. Capital budgeting decisions thus have a long range impact on the firm's performance and they are critical to the firm's success or failure. Since the firm's investment decision will have a long lasting effect on its cash flow the value maximizing process will be affected either positively or negatively, particularly in financial institutions (FIs). Financial institutions are the most sensitive and regulated sector that deal with financial resources. This implies, in theory, all investment projects undertaken by financial institutions should be critically evaluated by applying different capital budgeting techniques for the viability of investment of scarce resources in any long-term assets. Capital budgeting decision requires planning for setting up budgets on projects expected to have long-term implication. Now days, the techniques of capital budgeting are systematic. Financial institutions or any organization cannot control over its operation as per plan beyond the meaningful capital budgeting decision and application of capital budgeting techniques. Hence, capital budgeting decision and practice of capital budgeting techniques bear the significance and importance for success of financial institutions along with any other business.

As indicated in figure below, in order to achieve the overall objective of shareholders wealth maximization, firms should properly apply the different capital budgeting techniques and thereby make informed investment decisions. Capital budgeting is the process of identifying and choosing investments alternatives in assets expected to generate benefits over more than one year (Fabozi \& Peterson, 2003). There is general consensus that choosing the best investment alternative is the most important decisions made by corporations. The choice of projects and the level of investment are critical not just for stakeholders of the firm but also for the economic wellbeing of society as a whole (Harris And Raviv, 1996). In general, there are two approaches of capital budgeting: traditional and discounted. The traditional investment evaluation approaches have been useful in the past, when the business environments were easily predictable. However, with the today's business environment where things are more unpredictable and unstable the utility of the traditional investment evaluation approaches have been questioned greatly, in this regard Ashford, Dyson \& Hodges (1988) noted that the traditional appraisal methods of payback, discounted net present value (NPV) and internal rate of return (IRR) undervalues the long-term benefits; that traditional financial evaluation techniques assume too static view of future business activity, undermine the effects and pace of technological evoluation; that there are many benefits from investments in new technology which are difficult to quantify and are often ignored in the appraisal process.

Figure 1: Goal of the Firm and Capital Budgeting Process

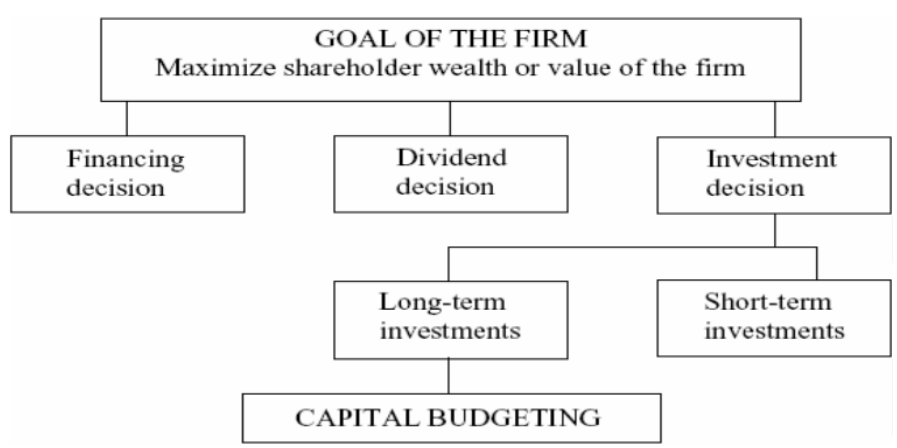

Source: Dayananda, Irons, Harrison, Herbohn and Rowland 2002

Capital budgeting is an important aspect of decision-making in organizations. Recent years have witnessed significant advancement in the use of capital budgeting approaches which range from simple cost-benefit analysis (CBA) to more complex decision-making approaches (Aman Khan, 
1987). In other word, capital budgeting is the planning process used to determine whether a firm's long term investments such as acquisition of new machinery, replacement of old machinery, new plants, new products, and research development projects are worth pursuing. It is budget for major capital, or investment, expenditures (Sullivan, et al. 2003). Optimization can, at least spontaneously, be seen as an approach in assessing capital allocation challenges (Luenberger, 1998). The empirical study of Abuzar Eljelly \& Abubakr Abuidris (2001) surveys the capital budgeting practice in private and commercially-oriented public sector corporations in the Sudan. Their study tried to fill a gap in the literature by documenting the capital budgeting practice in Sudan where the economic environment is different than the developed and developing counterparts and where public sector still plays a major role in the economy. Likewise, few studies have been done in the case of Ethiopia particularly on the capital budgeting practices in financial sector if not at all.

Since post 1991, the number of financial institutions in Ethiopia has been tremendously increasing because of the change in the economic philosophy from command to market economy where the role of private businesses is significant. Pre 1991, all financial institutions including the Central Bank were under the ownership of the public. Because of liberalization of the for example the number of banks were increased from 3 to 18 banks, of which only two are public and the remaining 16 are privet banks. As a result of increase in the number of banking firms in the country, the competition among banks are very stiff especially in terms of introducing new products to customer and expansion of branches.

In a competitive market the only way out to maximize profit for a given firm is through economies of scale since firms are price taker not price setter which is possible only in the monopolistic market. Financial institutions especially banks and insurances are the most regulated types of business in Ethiopia. Of course this sector is regulated not only in Ethiopia but also in the advanced economy too since the banking sector activity is directly related to the monetary policy of government. However, the level of restriction and regulation the sector is much more serious in Ethiopia than that of developed nations this is because of the fact that the sector is not yet matured in terms of the management practices and also the business environment in the country is almost at its infancy stage. Thus, the banking activities are strictly supervised by the National Bank of Ethiopia (NBE) even to the extent of setting the ceilings of the interest rate, asset composition, capital structure and foreign currency exchange rate which is almost liberal in other countries. In other word, financial institutions in Ethiopia meant just to implement or do businesses as they are told to do rather than becoming very creative by applying the very concepts of economics. Taking this presumption, the only means in which firms in the financial sector will be able to survive or make a profit is by increasing its outreach so that it can satisfy its customer thereby maximize shareholders wealth. Hence, in order to increase number of customers, the banks need to invest certain amount of resources on long-term assets including research and development projects so as to expand their businesses. To do such milestone projects, the firms in the sector should apply the different capital budgeting evaluation techniques so as to identify promising investment alternative that could uplift the company's profit thereby maximize shareholders wealth.

In Ethiopia context, it is difficult to imagine that customers are loyal to a given company as long as they can find similar product nearby their home, they don't hesitate to shift. In my view, there are only few customers, if none, are loyal to a given firm's product in Ethiopia. In other word, most people are loyal to the product but not for a given firm's product as long as they could find similar product at the time they need it. Hence, to be competent enough, private banks in Ethiopia should increase number of customer and also adopt new technologies such as Automatic Tailor Machine (ATM) as so to increase outreach since people in Ethiopia are loyal to access regardless of the additional service the firms provide. In order to increase outreach, banks must invest either new technology or/and increase new branches throughout the country. 
Literarily, adopting new technologies or expansion of branches are all an investment decisions that need critical evaluation which involves capital budgeting decision. Therefore, this paper aim at filling the knowledge gap using survey data to explore the capital budgeting practices of financial institutions in the country, Ethiopia.

Edward et al., (2001) focus that the early 1950s, the academic community has tried to convince corporate managers that there are sophisticated approach that can upgrade the capital budgeting decision-making phases. Over several years, large number of studies have documented a trend toward increasing business use of such sophisticated capital budgeting techniques. The simplest and commonly used capital budgeting technique that does not involve discounted cash flows is the simple rate of return. The method is also known as the accounting rate of return, the unadjusted rate of return, and the financial statement method. Unlike the other capital budgeting methods, the simple rate of return method does not focus on cash flows rather, it focuses on accounting net operating income/income. The approach is to estimate the revenue that will be generated by a proposed investment and then to deduct from these revenues all of the budgeted expenditure related with the project. The net operating incomes then related to the initial investment in the project.

Accounting rate of return (ARR) measures profitability from the historical accounting standpoint by comparing the required investment (sometimes average investment) to future annual earnings. Pradeep's Brijlal (2008) paper revealed that most businesses used the cost of bank loan as a basis in capital budgeting and more than two thirds of respondents used nonquantitative techniques to consider risk while making a decision on investing on long-term assets. Prather et al. (2009) determine how small rural companies use capital budgeting techniques; they surveyed 281 members of the Durant, Oklahoma Chamber of Commerce. Their goal is to determine whether these small rural firms practice what academics teach. Their survey covered a variety of discounted cash flow (DCF) and other traditional techniques and also examined the incidence and treatment of capital rationing. The survey design permits us to partition results to examine differences due to firm size, industry, form of business organization, firm age, age and education level of the primary decision-maker, and whether operations are international or domestic. They also examine the incidence and treatment of capital rationing. Finally, Prather et al. (2009) examine the methods applied to determine the required return and the use of sensitivity analysis, scenario analysis, and simulation. They also found that our sample firms operate in a far less structured manner than optimal. More than $71 \%$ of the sample firms did not have a written business plan. In addition, nearly $66 \%$ of the sample firms make capital budgeting decisions based on managerial judgment or "gut instinct." Moreover, when questioned about why sophisticated techniques are not used, more than $19 \%$ of respondents were not familiar with the techniques; another $19 \%$ did not believe using the techniques would affect profits, and $28 \%$ did not have the staff, time, or experience.

Rappaport and Taggart (1982) examined various methods for incorporating the effect of inflation into capital budgeting. They suggested an analysis which proved the differential effect of using a gross profit per unit method, a nominal cash flow approach (where individual forecasts are included into each parts of cash flow and a real cash flow technique in which a general price deflator is used to deflate nominal cash flows. They attempt to merge the simplicity of a gross profit per unit approaches of adjusting for inflation with the more realistic nominal cash flow and real cash flow approaches. However, in Ethiopia inflation is also an area where FIs have not paid much attention in their capital budgeting decision making. To sum up, few studies have done to addresses which capital budgeting techniques have been used by financial institutions in Ethiopia though the importance of evaluation is much said by different literature. The finding of this paper is similar to the finding of Eyob Dagne (2010) except the scope of the studies differs. The result of the study proved the fact that only one bank properly applied long-term investment evaluation technique while making investment on 
information technology. Similarly, except one firm, which conducts partial analysis about the feasibility, almost all other firms in the sector, FIs have applied capital budgeting techniques while making long-term investments particularly while opening new branches.

\section{OBJectives OF The STUdy}

A primary goal of the study was to explore the capital budgeting practices of financial institutions in Ethiopia.

In order to achieve the general objective, the following specific objectives set.

- To identify the mostly used capital budgeting techniques in financial institutions;

- To understand which project evaluation methods are commonly used under different types of investment;

- To explore the different qualitative approaches of investment evaluation considered by financial institutions while evaluating long-term investments;

- To see what discount rates do financial institutions uses while evaluating different investments; and

- To explore how financial institutions evaluate project risk, and thereby forward recommendation for further studies in the subject matter under study.

\section{Materials And Methods}

Descriptive research design was used since the use of this approach is sounder to address the research question understudy. Survey questionnaire, interview, and document review were used in order to collect both primary and secondary data respectively. The questionnaire used was a modified version of the one used by Burns and Walker (1991) in their capital budgeting survey of the Fortune 500 companies. Census survey was used to gather the data due to proximity of the authors' work place and all banks and insurance head offices and also the number of finical institutions was small. Hence, the questionnaire was sent to all banks and insurance companies in person. In order to increase the response rate, the author personally distributed the questionnaire and periodically reminded all the respondents through telephone, which makes the data collection similar to schedule methods of data collection. The only thing any researchers in Ethiopia agree is that, collecting data, particularly primary data, from firms in Ethiopia is very much tough if impossible. Though an effort was made to contact a sizeable number of financial institutions, only 10 banks and 4 insurance companies, which is around $38.9 \%$ of the total population, were replayed the questionnaire. Still the number of firms replayed the questionnaire were sufficient enough to generalize about the question under study since the composition of the firm was representative. The data collected though the aforementioned methods were analyzed using descriptive statistics methods and presented using tables.

\section{RESULTS AND Discussions}

This section summarizes the analysis and interpretation part of the paper. In order to address the objective of the study, most of the respondents' included were top-management of the organizations, those who are working on investment related activities of FIs.

\section{Capital Budgeting Evaluation Techniques Used}

Capital budgeting techniques are concerned with the ranking of investments for the decision of whether or not they should be accepted for inclusion in the capital budget. Like that of other businesses, some FIs in Ethiopia use different techniques for evaluating their investment partially. That means, of all firms in the sector, only six firms, almost $43 \%$, used various long-term investment evaluation techniques partially. In other word, more than $50 \%$ of firms in the sector were not yet implemented or used the various financial feasibility 
approaches. Hence, such firms were undertaken long-term investment just based on personal judgment/gut feelings or some other unknown formula. Moreover, even those firms in the sector who were using the different project evaluation techniques did not properly apply the project evaluation techniques while evaluating all investment such as expansion project (opening branches) as well as investment on new technologies. Of course, investment in new technologies might be analyzed in terms of its techniques viability however no detail financial feasibility were made so far as explored through interview, which is similar to the finding of Eyob Dagne (2010). From theory point of view, feasibility study includes not only technical aspects of the project but it also includes the market and demand; management structure; financial and economy; and social and environmental feasibility. Similarly, except one firm, which conducts partial analysis about the feasibility using PBP and simple break-even analysis, almost all other firms in the sector do not make detail evaluation about the viability of opening branches.

On the other hand, almost the six firms discussed above, fully use different various techniques while constructing or buying fixed assets such as building or land for future building site. Even though having internally developed investment evaluation guiding rule is crucial for top-management in making rational appraisal, only 3 firms have written guideline which direct firms in evaluating investment and passing the final decision of accepting or rejecting different projects.

Table 1: Capital Budget Evaluation Techniques

\begin{tabular}{|lccccccc|}
\hline & NPV & $\underline{\text { IRR }}$ & $\underline{\text { PI }}$ & $\underline{\text { DPBP }}$ & $\underline{\text { PBP }}$ & $\underline{\text { ARR }}$ & $\underline{\text { Total }}$ \\
No. of FIs & 2 & 1 & 0 & 0 & 3 & 0 & 6 \\
Percent & $33.3 \%$ & $16.7 \%$ & 0 & 0 & $50 \%$ & 0 & $100 \%$ \\
\hline
\end{tabular}

Source: Survey result

As shown in table above, of the firms those used project evaluation methods, most of the firms, 50\%, in the sector used Payback Period (PBP) as the most appropriate evaluation techniques while making long-term investments such as constructing or buying building. This might be because of the fact that, PBP as a tool of evaluating long-term asset is very easy to compute as well as straight forward to interpret even without technique knowledge of accounting and finance. Since the payback period is the number of years that is required for the business firm to recover from the project the amount of the initial investment in total. Thus, the shorter the PBP, the more the project is accepted for making investment. In other word, PBP will measure both the financial as well level of risk the project has. Thus, the use of PBP is somewhat convincing like that of other sophisticated project evaluation techniques such as Net Present Value (NPV) since it has dual mission. However, as long as PBP is a traditional approach of project evaluation, the modern schools of thought advocate the use of either NPV or Internal Rate Return (IRR) methods than that of the traditional methods since these techniques considers the timing of return and uncertainty of returns.

The net present value (NPV) method is an investment project proposals evaluating and ranking technique using the present value of future cash flows less present value of cash outflows, discounted at the given cost of capital, or opportunity cost of capital. But less than $34 \%$ out of firms those applied the different evaluation methods and only less than $15 \%$ the total firms surveyed were used NPV technique; whereas, only $7.14 \%$ of the total firms considered used Internal Rate Return (IRR) while making long-term investment evaluation. The internal rate of return is the discount rate which equates the present value the expected cash flows with the initial investment outlays. In other words, IRR is a method of ranking 
investment project proposals using the rate of return on an asset or investment. May be the reason, why most firms in the sector did not use both NPV and IRR is the difficulty of computation and interpretation of the methods as compared to PBP.

\section{Qualitative Approach used in evaluating projects}

There are different approaches of project evaluation. The most commonly used approach of investment evaluations is quantitative and qualitative. The quantitative approach uses different evaluation techniques such as PBP, NPV, IRR, and PI which consider only financial data while the qualitative approach uses non-financial data which are very important for the success or futurity of the project. Considering non-quantitative or non-monetary items in evaluating long-term investments are critical for the success the projects since the importance of a given project couldn't be evaluated solely through monetary items though objective.

Table 2: Qualitative evaluation

\begin{tabular}{|c|c|c|c|c|}
\hline Qualitative factors & $\begin{array}{l}\text { Very } \\
\text { little }\end{array}$ & $\begin{array}{c}\text { To a } \\
\text { great extent }\end{array}$ & $\begin{array}{c}\text { Not } \\
\text { applicable }\end{array}$ & $\begin{array}{l}\text { Total \& } \\
\text { Percent }\end{array}$ \\
\hline $\begin{array}{l}\text { a. The societal impact of the } \\
\text { project such as creating job } \\
\text { opportunities }\end{array}$ & 3 & & & $3=12 \%$ \\
\hline $\begin{array}{l}\text { b. The environmental impact of } \\
\text { the project }\end{array}$ & & 2 & 2 & $4=16 \%$ \\
\hline $\begin{array}{l}\text { Political effect of the } \\
\text { investment }\end{array}$ & & 10 & & $10=40 \%$ \\
\hline d. Organizational factors & 4 & 4 & & $8=32 \%$ \\
\hline Total \& Percent & $3=28 \%$ & $16=64 \%$ & $2=8 \%$ & $25=100 \%$ \\
\hline
\end{tabular}

Source: Survey Results

As shown in the table, most firms (40\%) of the firms in the sector consider the impact or the effect of the project from the political point of view to great extent (62.5\%). The next best qualitative factor that took attention of the sector is the impact of the project on the overall organizations aspect such as strategic alignment of the project to a great extent (25\%). Contrary to this, less attention was given to the societal impact of the projects. On the other hand, consideration given to the environmental effect of the projects was a mixed result which ranges from no consideration to a great extent emphasis. This result was the same as to the above analysis.

\section{Discount Rate Used in Capital Budgeting}

The discount rate is usually called as cost of capital or required rate of return. The concept of capital is based on the assumption that the core goal of profit-Seeking business firms is to maximize the wealth of shareholders. The concept of cost of capital has its roots in the items on the right-hand-side of the balance sheet, which includes various types of debt, preferred stock, common stock, and retained earnings. An increase in total asset must be financed by an increase in one or more of these capital components. Capital is one of the necessary components of production/operation of a business firm, and like any other factor it has a cost of its own. Theoretically, it has been said that, finance managers should use this discount rate while evaluating long-term investment. 
Table 3: Types of Rate of Discount used

\begin{tabular}{|l|c|}
\hline Type of ROD & Percent \\
\hline Cost of Capital & 0 \\
\hline Interest on Treasury Bill & 0 \\
\hline Average Bank interest rate & 80 \\
\hline Not Given & 20 \\
\hline Total & $100 \%$ \\
\hline
\end{tabular}

Source: Survey results

Of those FIs properly evaluates their long-term investment using capital budgeting techniques, almost all $(80 \%)$ of the firms consider average bank interest rate on loan as the main discount rate. This might be because of the fact that the computation of the actual cost of capital is difficult to compute if impossible. The use of interest on debt as a discounting factor, cost of capital was suggested by Franco and Merton (1958) and now accepted in modern finance theory of investment. According to Modiglian and Merton, the cost of capital is equal to the rate of interest on bonds, regardless of whether the funds are acquired through debt instruments or through new issues of common stock.

On the other hand, the surprising thing is that, the remaining (20\%) of the banks even do not have any specific discount rate to evaluate any investment project regardless of the importance of the investment. Hence, they do not use the modern project evaluation techniques such as NPV, IRR and PI instead they use PBP since it's easy to use and interpret too.

\section{Project Risk Evaluation Techniques}

The optimum capital budget is simultaneously determined by the interaction of supply and demand forces under conditions of uncertainty. The forces of supply refer to the supply of capital to the firm, or its cost of capital schedule. The forces of demand on the other hand, refer to the investment opportunities available for the firm, as measured by the stream of revenues that will result from an investment decision. Uncertainty of conditions enters the decisions because it is impossible to know exactly either the cost of capital or the stream of revenues that will be derived from a project. Future is full of uncertainties because of so many reasons such as inflation and other factors which are under the condition of changes. Project risk is defined as the adverse deviation of expected outcome from expectation.

In capital budgeting, projects' risk can be seen at three levels: first, there is a total project risk, which is a project's risk ignoring the fact that much of this risk will be diversified away as the project is combined with the firm's other projects and risks; second, we have the project's contribution to firm's risk, which is the amount of risk that the project contributes to the firm as a whole; this measure considers the fact that some of the project's risks will be diversified away as the project is combined with the firm's other projects and assets, but ignores the effects of diversification of the firm's shareholders. Finally, there is what is known as a systematic risk, which the risk of the project from the viewpoint of a welldiversified shareholder; this measure considers the fact that some of the project's risk will be diversified away as the project is merged with the company's other projects, and in addition some of the remaining risk will be diversified away by shareholders as they combine this stock with other stocks in the portfolio. Hence, all business organization should consider the risk element of projects while evaluating investment alternatives. 
Table 4: Techniques used to assess a project's risk

\begin{tabular}{|lccc|c|}
\hline Technique & Sometimes & Many times & Total & Percent \\
\hline Sensitivity analysis & & 5 & 5 & $83.33 \%$ \\
Other & 1 & & 1 & $16.67 \%$ \\
\hline
\end{tabular}

Source: Survey results

As indicated in the table above, however, the risk evaluation techniques used by the firms in the sector were not uniform though they deliver almost identical service to their clients. Most FIs (83.33\%) used sensitivity analysis while evaluating risk whereas the remaining firms used different risk evaluation approach such as breakeven analysis while making long-term investments. This variation may be because of the absence of written risk evaluation technique in the industry or because of lack of knowledge about the appropriate evaluation techniques or to the worst case it may be because of total negligence. Moreover, though the few of the firms in the sector used the risk evaluation techniques, they did not apply usually or always. That means they mostly used sometimes. On the other hand, firms do not make properly post completion audit periodically except few.

\section{CONCLUSION}

Long-term investments are also called capital budgeting. Thus, the capital budget of the firm outlines the planned expenditures on the fixed assets, and capital budgeting is the whole process of analyzing projects whose returns are expected to extend beyond the period of one year and deciding which project should be included in the capital project. Capital budgeting expenditures include expenditures for land, building, equipment, and for permanent additions to working capital associated with plant expansion, for advertising and promotion campaigns, and for research and development programs.

Evaluating long-term investment of firms using different capital budgeting techniques is critical since it helps top-management in making informed decisions. This enables the firm to be competitive in the market by keeping its existing customers. Before the firm spends a large amount of money, it must take the proper plans. Large amounts of funds are not available over night. A firm that contemplates a major capital expenditure program may need to arrange its financing several years in advance to be sure of having the funds required for the program.

Currently, financial institutions in Ethiopia are undertaking huge investments on different projects such as expansion of branches, acquisition of technological products and constructing own large building throughout the country. Even if the firms in the sector were made significant investment on such long-term assets only $42.9 \%$ of the firms were properly used the modern approaches of investment evaluation approaches. Similarly, except one firm, which conducts partial analysis about the feasibility, almost all other firms in the sector did not made detail evaluation about the viability of opening branches. As explored about the reason why, through interview top-management of the organizations as well as review of secondary data, opening branch is mandated by the government as a policy issue not the feasibility concern. Even those few who undertake feasibility study to open branches were not the final decision maker to open or not to open as clearly stated in the government policy direction of increasing outreach of FIs to the society regardless of viability. Still they are more systematic in diverting their scarce resources to some productive areas and projects by delaying immediate investment if opening branch in a specific area is not feasible. However, if a given FI does not make detail analysis about the feasibility of 
opening branch in a specific area, such investment will miss the logic and becomes just trial and error than scientific way of allocating resources. The outcome of such unsystematic way of investment on expansion made most banks' branches to exercise loss since their establishment. Similarly, now a days, though most FIs were making huge investment on different projects, no or few studies have been done to explore the viability of such projects particularly investment in new technologies have no financial feasibility is made as interview made with FIs managers. That means, may be only technical feasibility of the technologies have done ignoring the financial, market and economic impact of the project.

On the other hand, few FIs (30\%) were made detail financial feasibility analysis while making investment in constructing new building. The surprising thing is that, almost all FIs consider or see the financial feasibility of their debtors while proofing the credit worthiness and the financial viability of the debtors' project so as to lend money. For the author the contradicting issue (the so called double standard) is that, if FIs use the different capital budgeting evaluation techniques to examine the financial viability of the debtors, why FIs themselves do not properly use the techniques while making investment in long-term assets? Well, still for me, the hypothetical answers for this question are: - May be

1) Top-management of FIs in Ethiopia may not clearly know the importance of capital budgeting for the success of the firms but they implement on their debtors simply to build their confidence and pretend their debtors as if they are serious in making decisions.

2) FIs do not consider projects undertaken by themselves on long-term assets as investment. That means, managers in the sector considers providing loan to their debtors as the only investment. FIs in Ethiopia consider only how to generate income from investment in the form of loan as a means of maximizing shareholders wealth. In other word, FIs do care only cash flow from loan and they don't care about how to utilize the income generated from it. Of course, the main source of income as well as cash flow is related to investment in the form of loan to debtors. However, this doesn't mean that, investment in other projects should be ignored particularly in developing country like Ethiopia, where FIs are infant in terms of their capital as well as age. Since the sector is very young, firms in the industry must need to invest huge resources in different assets such as technologies. And /or

3) The restrictive nature of FIs regulation in Ethiopia may not allow firms in the sector to make detail evaluation to invest on long-term projects. This may be true only in the case of expansion types of project, opening of new branches, since the government forces the firms in the sector to open branches throughout the country so as to achieve the FIs outreach policy of the government.

Of those FIs properly evaluating long-term investment, the most commonly used evaluation techniques are PBP, NPV and IRR respectively. The main reasons for using PBP technique mostly, (50\%), was because of simplicity and applicability of the evaluation approach. On the other hand, most firms in the sector used average bank interest rate as a discount rate while evaluating long-term assets using net present value. This is because of the fact that, the computation of the actual cost of capital is difficult if impossible in Ethiopia context where there is no well-developed capital market. In a similar vein, less than $30 \%$ of firms in the financial sector, of those apply capital budgeting techniques while evaluating long-term assets, used risk evaluation approaches. The most commonly used risk evaluations techniques is a simple break-even analysis and rarely sensitivity analysis. Moreover, the 
qualitative factors were rarely implemented or considered while evaluating investment on long-term assets by firms in the FIs in Ethiopia except the impact of the project on the politics.

Even though the philosophy of using capital budgeting techniques while evaluating investment on fixed assets were not new, most firms in the FIs in Ethiopia, of those properly using, started using or implementing the approaches not more than five years from now. Surprisingly, still most of the firms do not have written guidelines for evaluating investments. That means, managements make decision based on their personal judgment which might create subjectivity. More than $95 \%$ of firms in the sector do not have fulltime employee which deal with feasibility studies. These indicate that, the emphasis given to the importance of evaluating investment in different fixed assets using various capital budgeting techniques were less. In my view as well the interview result indicates that, now a day, the sector is very easy to generate a profit as long-as the business run under strict rules and regulations and also the market is not open for international firms. In other word, though becoming extraordinary in the sector was difficult, making average profit is a "business as usual". That means, to make an average profit no efforts is needed by employing staff who can handle research and /or investment evaluation since most firms income were generated from money transfer both domestic as well as foreign currencies. However, if the sector is made free for international firms to enter, most firms will suffer a lot of problem to make profit if survived since much income is generated from money transfer mainly from abroad, which is hard currency.

Obviously, business as usual doesn't work in the long-run as the government is planning to make the sector free/open to the international firms in the near future since different international development partners are reinforcing the government through "stick and carrot" approach. Hence, if the sector is made open for international firms, this might by hook or cook forces domestic firms in the sector to use the capital budgeting techniques so as to evaluate any investment on fixed assets for the sake of survival if wealth maximization is impossible since international firms are strong enough in terms of their management skill as they do have ample business experience.

\section{ReCOMmEndation AND POLICY IMPLICATIONS}

- As explored through survey questionnaires, interview, and other related queries most firms in the financial sector in the country did not have any written guidelines on the use of capital budgeting techniques. Moreover, almost all firms did not have fulltime staff who can deal with long-term investments of company. Hence, the topmanagement should develop clear investment evaluation criteria; and also there is need to assign more full time staff to a crucial aspect as investment analysis and involve them in production and review of guidelines pertaining to capital expenditure.

- Since adoption of different investment evaluation techniques are critical for the success of the firm, businesses should implement at least the traditional approaches of longterm investment if the discounted methods are impossible.

- The national bank of Ethiopia (NBE) is the central bank that oversees the activities of all financial institutions including the minimum level of capital, interest rate, and exchange rate as a policy guide. In other words, all the activities of FIs are based on the direct instruction from the NBE. However, the competition in the sector may be stiff in near future especially if the industry becomes open to international firms, who are familiar 
with different investment evaluation techniques. Therefore, in order to make domestic firms in the sector, NBE should assist all financial institutions in adopting the capital budgeting techniques since some of the investment decisions are made in line with government policy direction than merrily the firm's interest.

\section{REFERENCES}

Abuzar M. A. Eljelly \& Abubakr M. Abuidris (2001). A Survey of Capital Budgeting Techniques in the Public and Private Sectors of a Less Developed Country (LDC), Journal of African Business, Volume 2, Issue 1, pp $75-93$.

Aman Khan (1987). Florida International University. Capital Budgeting Practices in Large U.S. Cities. Published in: The Engineering Economist, Volume 33, Issue 1, pp.1 -12.

Ashford R. W., Dyson R. G., Hodges S. D. "The Capital-Investment Appraisal of New Technology: Problems, Misconceptions and Research Directions" The Journal of the Operational Research Society, Vol. 39, No. 7 (Jul., 1988), pp. 637- 642

Burns, R., \& Joe, W. (1991). Selection Techniques in Capital Budgeting: A Rational Investigation. Paper presented at the South Central Finance Workshop.

Dayananda D., Irons R., Harrison S., Herbohn J and Rowland P. (2001) "Capital Budgeting: Financial Appraisal of Investment Projects" Cambridge University Press.

Edward J. Farragher Robert T. Kleiman Anandi P. Sahu (2001). A Oakland University, Michigan York University, The Association between the Use of Sophisticated Capital Budgeting Practices and Corporate Performance, Published in: The Engineering Economist, Volume 46, Issue 4, pp $300-311$.

Eyob Dagne, 2010, Capital Investment Decisions on IT and Its Impact on Corporate value maximization the case of Ethiopian Financial Institutions, unpublished MSc Theses.

Fabozzi FJ and Peterson PP "Financial Management and Analysis" 2nd Edition 2003 John Wiley \& Sons, Inc. USA pp 356-358

Franco M and Merton H. M (1958), The Cost of Capital, Corporation Finance and the Theory of Investment, The American Economic Review, Vol. 48, No. 3, pp. 261-297

Harris M and Raviv A "The Capital Budgeting Process: Incentives and Information" The Journal of Finance, Vol. 51, No. 4 (Sep., 1996), pp. 1139-1174

Luenberger D. (1998), Investment Science. Oxford University Press, New York.

Pradeep Brijlal (2008). University of the Western Cape, Australasian Finance and Banking Conference Paper.

Prather LJ, Topuz JC, Benco DC, Romer DA. (2009). "Capital budgeting practices of small businesses: evidence from rural America". J. Bus. Entrep. 21(1):1-14.

Rappaport A. and Taggart RA. (1982). Evaluation of Capital Expenditure Proposals under Inflation," Financial Management, pp. 5-14.

Sullivan, Arthur; Steven M. Sheffrin (2003). Economics: Principles in action. Upper Saddle River, New Jersey Pearson Prentice Hall. pp.375. 